

\title{
Factors Influencing Performance of Pension Funds: Evidence From Lapf in Tanzania
}

\author{
Hadija Matimbwa \\ Lecturer Faculty of Business and Management Science, Ruaha Catholic University
}

\begin{abstract}
Pension funds are an important incentive to capital markets in most countries where they exist through financial intermediation. Pension funds complement and stimulate development of capital markets while acting as substitutes for banks as they generate returns themselves. The returns they realize depend on several factors that vary from country to country and from time to time. The purpose of this study was to determine factors influencing performance of pension funds in Tanzania specifically at the Local Authority Pension Fund (LAPF). This study used a quantitative research approach where questionnaires were employed to collect data. Probability sampling was used as well to select a representative sample from each stratum. Descriptive statistics such as percentages and frequencies were used to analyze data collected from respondents. SPSS version 20 and excel Microsoft application were ultimately used to process the data.

Findings from this study indicate that economic hardships faced by many companies result in firms winding up their businesses with arrears of members' contributions and this results into delay in benefit processing.

Additionally, late submission of collected contributions from employers' delays benefits processing. The study further reveals that employers who default in making contributions as legally required hamper benefits payments. The study equally exposes the fact that arrears in contributions result in delayed payment. The results also demonstrate that businesses with arrears contribute to delay of benefits processing. The study recommends that LAPF should devote more time in enlarging its membership frontiers to ultimately increase members' contributions.
\end{abstract}

Keywords: Pension Fund

\subsection{Background to the Study}

In the recent past, many countries around the globe have experienced rapid establishment and growth of pension funds. The growth of these institutions is one development that countries have given considerable attention to because of the sensitivity of the transactions involved in pension funds. Pension funds act as an important incentive to capital markets in most countries where they exist through financial intermediation. Pension funds tend to complement and stimulate development of capital markets while acting as substitutes for banks. The growth of 
pension funds is highly considered a consequence of a number of non-financial and demandside features (Davis, 2000).

The need for better managed pension funds in many countries has been necessitated by population increase around the world. Most developed and developing countries are experiencing increasing longevity in life expectance and reduced fertility rates that seem to threaten the sustainability of traditional pay-as-you-go pension systems. Pension contributions from the working population are insufficient to support the elderly. In response, countries are increasingly shifting their pension systems toward partial or full funding. In addition to the main purpose of coping with demographic pressures and unsustainable fiscal positions, other motivations for countries to reform their pension systems often include the hope that funded pensions will contribute to economic development by promoting national savings and capital market development (Meng and Pfau, 2010).

Pension funds perform diverse activities that are beneficial to both individuals and the economy at large. For instance, the funds induce capital and financial market development through their substituting and complementary roles with other financial institutions, specifically commercial and investment banks. As competing intermediaries for household savings and corporate financing (Impavido, Musalem, and Tressel, 2002), pension funds foster competition and may improve the efficiency of the loan and primary securities markets. These results in a lower spread between lending rates and deposit rates and lower costs to access capital markets. On the other hand, Davis (2000) argues that pension funds may complement banks by purchasing long-term debt securities or investing in long-term bank deposits. Other potential impacts from the growth of pension funds include an inducement towards financial innovation, improvement in financial regulations and corporate governance, modernization in the infrastructure of securities markets, and an overall improvement in financial market efficiency and transparency (Davis, 1995). Such impacts should ultimately spur higher longterm economic growth.

The performance of pension funds depend mainly on the growth of members, amount of contributions collected, returns from investments, and payments made to beneficiaries. Performance of funds based on member registration depends on an increase in the number of members to meet the target set by an organization. For stance, if LAPF sets and achieves its target of registering 24,000 new members then the pension fund has performed well.

It should be noted that for some reason an organization may not meet its set target. Among other reasons, low employment rates within both the government and private sector may enormously affect any pension fund's set target. Additionally, if a country has various pension firms, competition for clients greatly reduces the membership margin of every pension firm.

Another performance indicator is the increase in contribution which is commensurate to increase in membership and increase in salary levels of members. It goes without saying that the more clients a pension firm has, the wider the contribution margin. The contribution margin is equally affected by increase in the salaries of clients.

Contribution also largely depends on the compliance rate of employers. When employers diligently adhere to contribution policies set by pension firms, contributions are bound to increase. In sum, challenges facing increment in contributions in LAPF including low rate of members registered, insignificant or no salary increase of members, unawareness among stakeholders, and low level of employer-compliance all lead to underperformance of LAPF.

The income from investment depends also on the intensity of investment. It is important to note that $75 \%$ of the amount collected from members is invested. The income from investment is 
used to meet the organization's expenditures and create the value for money of members' contribution. The economy poses a challenging investment climate due to limitations in investment choices as the stock market is still underdeveloped. This is further exacerbated by onerous fiscal policies. In response thereof, the Fund has continued to rely on Governmentguaranteed projects. Bank deposits on real estate remain a major alternative investment avenue.

The Fund spends the greatest share of its income on benefit payment. LAPF is ranked second in the country because of the number of benefits offered. Currently, the fund offers six types of benefits including retirement benefit, survivorship benefit, invalidity benefit, withdrawal benefit, maternity benefit, and funeral benefit. The positive cash flow from the Fund enables timely payment of benefits. This signifies the financial stability of the fund and the ability to meet members' obligations for the foreseeable future. The big challenge facing benefit payment is how to maintain a positive cash flow relative to increase in benefit payment.

Despite the aforementioned challenges facing LAPF, there are no studies that have attempted to establish the key factors that affect the performance of pension funds. These factors greatly affect the milestones that pension firms can achieve and the lump sum pensioners eventually receive. This study establishes the determinants of performance of pension funds in the Tanzanian context in order to bridge the mentioned gap.

\subsection{Literature Review}

\subsection{Age of Members and Performance of Pension Funds}

The retirement age is an important aspect that determines the performance of pension funds. More specifically, when the accumulation period is shorter in countries that allow individuals to retire earlier, individuals are likely to receive lower retirement income. As a consequence, governments in some countries have been raising the official retirement age or have introduced incentives to delay retirement. The capacity of funded individual account systems to deliver retirement income will be further challenged in this respect as life expectancy continues to increase in virtually all countries. Moreover, the age of an investor has a significant impact on the performance of the pension fund as it is obvious that younger members automatically make more contributions compared to their older counterparts (Kiplagat, 2014).

Puttonen (2005) empirically examined the strategic asset allocation and the asset/liability issues in the Finnish defined benefit pension funds in Finland. His study focused on the pension funds of the income-related defined benefit TEL-scheme. Benefits of the income-related scheme are a structure of number of years of employment, age-weighted accrual rate, and wage. Data were collected by using both questionnaires and documentary review. Similarly, regression analysis was employed to analyse the data. Therefore, at the end of the study, findings revealed that liability structure of a pension fund affects its asset allocation. The correlation and regression analyses provide evidence that there is a relation between age structures and the strategic asset allocation of pension funds. The average age of employees seems to better explain the proportional equity investment than the proportional fixed income investment. When the solvency variable is added to the proportional equity investment model, the coefficient of determination improves.

\subsection{Assets and Performance of Pension Funds}

Omondi (2013) carried out a study titled"Relationship between asset allocation and performance of pension funds in Kenya". The quantitative data was collected by using questionnaires and analysis was done by employing correlation and regression models. The analysis of the findings was that the weight of immovable property scheme was strongly correlated to pension schemes financial performance. The study also noted that the weight of 
unquoted equities was strongly correlated (Pearson correlation coefficient $=.727$ ) to pension scheme financial performance. A (Pearson correlation coefficient $=.601$ ) was established between the weights of quoted equities in pension schemes financial performance.

Ammann and Ehmann (2014) carried out a study to establish the relationship between governance, asset allocation, and performance of pension funds in Switzerland. Data were collected from both primary and secondary sources. For secondary data, information on assets owned by the fund were obtained from financial statements and for primary data questionnaires were used. Regression and Correlation were employed to analyze the data obtained from the study. The findings of the study were that asset allocation weights of Swiss pension portfolios are primarily related to non-governance-related factors such as size, legal form, and the ratio of active plan members to pensioners. Since larger pension funds have more investment opportunities and more comprehensive internal risk management structures, they are able to invest in riskier asset classes that promise higher returns. Large pension funds in Switzerland hence "buy" a significant part of their superior performance with higher volatility as indicated by the analysis (Moses, 2013).

Nguthu (2009) in his research to establish how much asset allocation policy contributed to the returns level retirement benefit fund in Kenya found that the variation in returns over time for pension schemes is explained up to $62.4 \%$ by investment policy adopted by the trustees of the scheme. Other factors such as securities selection, timing of investments and managers' selection explained the remainder. The study was conducted on 40 segregated occupational schemes in Kenya and returns analyzed using regression analysis and descriptive statistics.

Despite the studies carried out locally on portfolio allocation and performance of pension funds, there are no studies that have attempted to explain the effect of asset allocation on the financial performance of Pension funds in Tanzania. The current study intends to address this research gap by posing the following research question: What is the effect of asset allocation on the performance of pension funds in Tanzania?

Moreover another study titled "Effects of assets allocation on financial performance in Kenya" was conducted by (Kiplagat, 2014). The main objective of this study was to determine the effect of assets allocation on the financial performance of pension schemes. This research was conducted through a descriptive survey and utilized secondary data available from RBA and Fund Managers. From the study, it was found out that there is a linear correlation between fund performances and the returns of the various asset classes with the strongest correlation being between overall fund performance and returns in equities, fixed deposit, and Government securities. From a population of 1297 schemes in Kenya, the findings of the study showed that asset allocation explained $89.5 \%$ of the variability of fund performance and that $10.5 \%$ was due to other factors such as the manager's selection, timing of investments, and securities selection within as asset class and the management style adopted by the fund managers of the fund. The study recommended that a related review should be carried out replacing actual weights of assets with a departure/deviation from the weights recommended by RBA to determine if the same conclusions of the study will still hold.

\subsection{Members Contributions and Fund Value Influence Performance of Pension Fund}

Sawick and Ong (2000) conducted a study titled "Evaluating Managed Fund Performance" in Australia. The study used conditional models (based on the semi strong form of market efficiency model of Fama). Regression and correlation analysis were conducted to analyse these data. Findings revealed that sound fund value enables pension funds to increase lump sum to retirees and also ensure invalidity and survival. The study further pointed out that a sound fund value which is obtained from members' contributions enables the fund to carry out more 
investment. The study clarified that funds hold stocks that outperform the market by 1.3 percent per year but their net returns underperformance of nonstick holdings, which was 1.6 percent was due to expenses and transactions costs. Thus, funds pick stocks well enough to cover their costs.

Again, Walker and Iglesias (2010) in their study titled "Financial Performance of the Pension Funds" established that members' contributions increase liquidity of the fund which facilitates timely payment of pensioners. The study further revealed that the fund value of the pensions fund enables them to pay tax for all investments and enables them to expand not only membership but also branches to accommodate services offered. The study further clarified that fund value encourages investment and highly benefits members of the pension fund.

All in all, literature reviewed suggests that there are contradictory views on the factors affecting the performance of pension funds which implies that the question of performance of pension fund services is debatable and yet to be fully clarified in terms of dimensions that truly associate with pension funds' performance.

However, much as there are yardsticks used to determine the performance of pension funds, it is clear that most pension funds are still at their infancy and this makes it difficult to create any meaningful trend analysis on their performance. Studies linking performance of pension funds for most developing countries are also scarce since they do not have well-structured pension plans due to inadequate regulations.

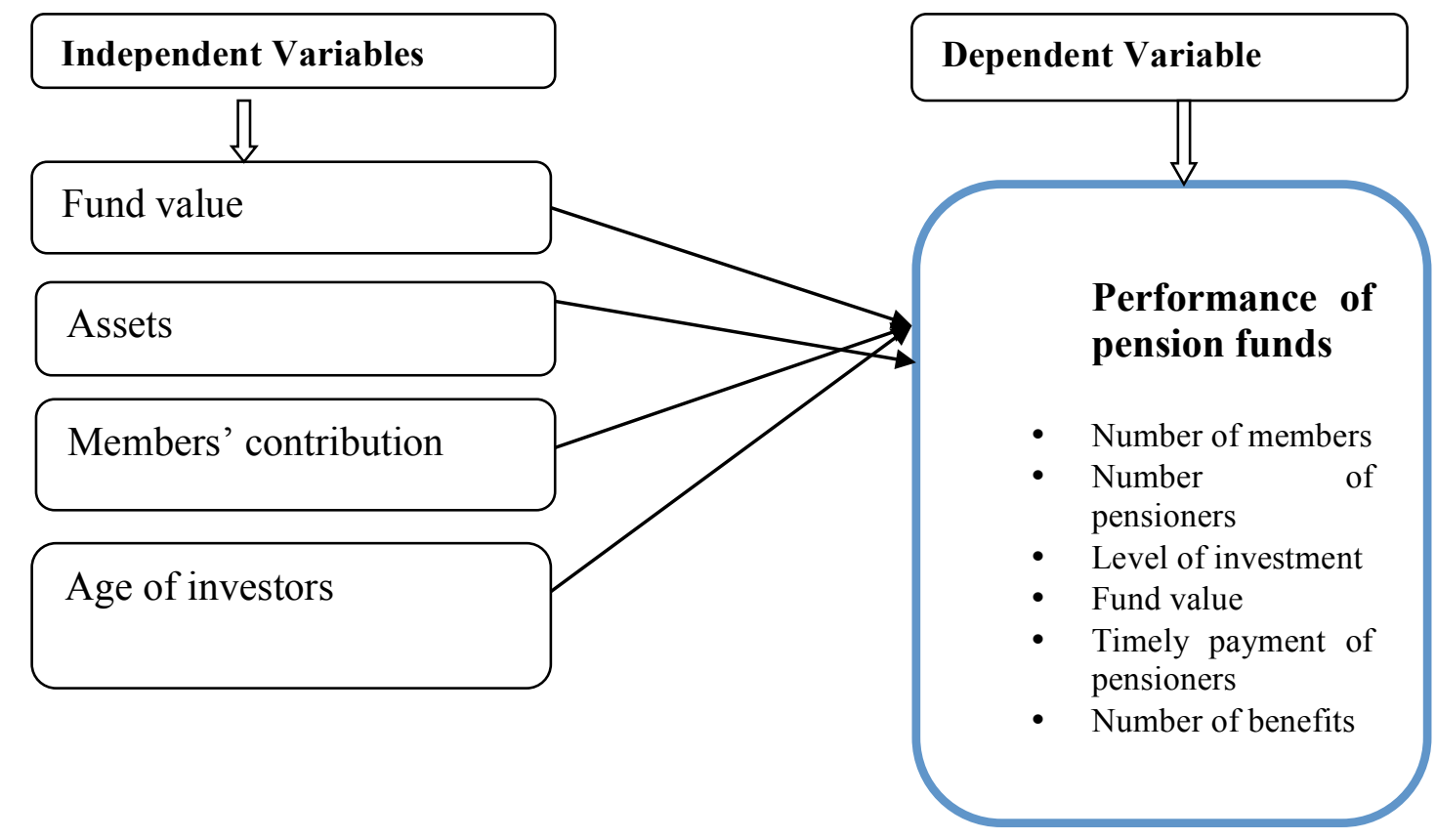

Figure 2.1 Conceptual Framework Showing the Relationships between Variables

Source: Researcher, 2018 
Journal of Business School, vol.2, issue.4, pp.69-81

Table 2.2 Variables and their Measurements

\begin{tabular}{|c|c|c|}
\hline Type of Variable & Description of Variables & Variable Measurement \\
\hline \multicolumn{3}{|l|}{ Independent Variables } \\
\hline \multirow[t]{2}{*}{ Fund Value } & Actuarial Valuation & $\begin{array}{l}\text { - Assets and liability } \\
\text { - Current values of assets } \\
\text { - Present value of the projected cash } \\
\text { flows from investments }\end{array}$ \\
\hline & Actuarial Value Assets & $\begin{array}{l}\text { - Actuarial value of assets exceeds } \\
\text { accrued liabilities (actuarial surplus) } \\
\text { - Actuarial value of accrued liabilities } \\
\text { exceeds actuarial value of assets } \\
\text { (actuarial deficit) } \\
\text { - Actuarial value of assets matches } \\
\text { accrued liabilities. }\end{array}$ \\
\hline \multirow[t]{4}{*}{ Assets } & Asset allocation & $\begin{array}{l}\text { - Number of investment in real estate } \\
\text { - Number of shares (dividends) } \\
\text { - Fixed deposits } \\
\text { - Government securities } \\
\text { - Outstanding loan amount }\end{array}$ \\
\hline & Categories of Assets & $\begin{array}{l}\text { Asset categories are Properties, Equities, } \\
\text { and Fixed Income Assets }\end{array}$ \\
\hline & Investment policy & $\begin{array}{l}\text { Rules, principles, guidelines proposed by } \\
\text { an organization, and BOT on investment. }\end{array}$ \\
\hline & $\begin{array}{l}\text { Investment } \\
\text { Valuation/Analysis }\end{array}$ & $\begin{array}{l}\text { Assessing of investment opportunities in } \\
\text { order to determine their technical and } \\
\text { financial viability or to compare and } \\
\text { choose between alternatives }\end{array}$ \\
\hline Age of the contributor & $\begin{array}{l}\text { At what Age the Member } \\
\text { Joined the Fund }\end{array}$ & $\begin{array}{l}\text { - Period of contribution } \\
\text { - Amount contributed by members } \\
\text { - The younger people who joined the } \\
\text { fund will contribute for a longer period } \\
\text { compared to those who joined the fund } \\
\text { at an older age. } \\
\text { - Excess contribution/cash invested. }\end{array}$ \\
\hline \multicolumn{3}{|l|}{ Dependent Variable } \\
\hline Pension Fund Performance & $\begin{array}{l}\text { Member registration, } \\
\text { Contributions from } \\
\text { members and investment } \\
\text { Income. }\end{array}$ & $\begin{array}{l}\text { - Number of members } \\
\text { - Number of pensioners } \\
\text { - Level of investment } \\
\text { - Fund value } \\
\text { - Timely payment of pensioners } \\
\text { - Number of benefits }\end{array}$ \\
\hline
\end{tabular}

\subsection{Research Methodology}


This study used a quantitative research approach whereby questionnaires were employed to collect the data. The study adopted a case study design to determine the influence of fund value, age of investor, members' contribution, and assets on pension fund performance. Questionnaires were used as a survey instrument. Data were collected by using structured questionnaires. Descriptive statistics were used to analyze data collected from the respondents and SPSS version 20 and excel Microsoft application was used to process the data.

\subsection{Results}

\subsection{Demographic Characteristics}

In this study, in order to have a better understanding of the demographic characteristics and specifications of the respondents, frequency analysis was used. The samples of the questionnaires were taken to LAPF employees whose sample size was 66 respondents. In total, five questions gave a brief overview of the demographic attributes of respondents as presented below:

Table 4.1

\begin{tabular}{|l|l|c|c|}
\hline Variable & Categories & Frequency & Percentage (\%) \\
\hline \multirow{5}{*}{ Sex } & Male & 42 & 63.6 \\
\cline { 2 - 4 } & Female & 24 & 36.4 \\
\hline \multirow{5}{*}{ Age } & $18-24$ & 15 & 22.7 \\
\cline { 2 - 4 } & $25-34$ & 34 & 51.5 \\
\cline { 2 - 4 } & 35 and above & 17 & 25.8 \\
\hline \multirow{5}{*}{ Education Level } & Certificate level & 3 & 4.5 \\
\cline { 2 - 4 } & Diploma level & 8 & 12.1 \\
\cline { 2 - 4 } & Degree level & 34 & 31.5 \\
\cline { 2 - 4 } & Others(CPA, PSPTB) & 21 & 31.8 \\
\hline \multirow{5}{*}{ Working Experience } & $1-5$ years & 19 & 47.0 \\
\cline { 2 - 4 } & 6-10 years & 14 & 21.2 \\
\cline { 2 - 4 } & 11 and above & 31.8 \\
\hline
\end{tabular}

Source: field data (2018)

The study involved a sample of $66(100 \%)$ respondents who filled in the questionnaires. 42 $(63.6 \%)$ of the respondents were male and $24(36.4 \%)$ were female. The results in the table above reveal that there was a slight difference between male and female respondents. Therefore, gender was seriously taken into consideration to collect data from the respondents (Table 4.1).

The study findings show that $15(22.7 \%)$ respondents were aged between 18 and 24 years. 34 (51.5\%) respondents were from the ages between 25 to 34 years. The statistics signify that all age groups were considered for employment by the selected organization. However, a large number of employees who were more than half were from the age group between 25 to 34 years. This implies that employees aged between 25 and 34 years cover the production level and are available in the labor market.

Lastly,34 (51.5\%) of the respondents were university graduates and $21(31.8 \%)$ were holders of Masters Degrees, CPA or PSPTB. Therefore, the statistics indicate that all categories of academic qualifications or awards were considered by the selected organization during recruitment. 


\subsection{Influence of Fund Value on LAPF Performance}

In the current study, the researcher was interested in establishing how fund value influences pension fund performance. The researcher therefore posed seven questions to respondents who were requested to point out issues they agree with or disagree with.

Table 4.2 shows the findings as follows:

Table 4.2 Influence of fund value on performance

\begin{tabular}{|l|c|c|c|c|c|}
\hline & $\begin{array}{l}\text { Strongly } \\
\text { Disagree }\end{array}$ & Disagree & Neutral & Agree & $\begin{array}{c}\text { Strongly } \\
\text { Agree }\end{array}$ \\
\hline $\begin{array}{l}\text { Excess fund encourage more } \\
\text { investment }\end{array}$ & Perc (Frq) & Per (Frq) & $\begin{array}{c}\text { Per } \\
\text { (Frq) }\end{array}$ & $\begin{array}{c}\text { Per } \\
\text { (Frq) }\end{array}$ & Per (Frq) \\
\hline $\begin{array}{l}\text { Excess fund leads to more } \\
\text { members benefits }\end{array}$ & $0(0.0)$ & $0(0.0)$ & $13.6(9)$ & $65.2(43)$ & $21.2(14)$ \\
\hline $\begin{array}{l}\text { Excess fund value enables LAPF } \\
\text { to grant loans to its customers at } \\
\text { a reasonable interest rate. }\end{array}$ & $0(0.0)$ & $0(0.0)$ & $25.8(17)$ & $39.4(26)$ & $34.8(23)$ \\
\hline $\begin{array}{l}\text { Sound fund value enables LAPF } \\
\text { to increase lump sum to retirees, } \\
\text { invalidity and survival }\end{array}$ & $0(0.0)$ & $0(0.0)$ & $24.2(16)$ & $53(35)$ & $22.7(15)$ \\
\hline $\begin{array}{l}\text { Fund value enables LAPF to } \\
\text { grow in terms of number of } \\
\text { branches and services }\end{array}$ & $0(0.0)$ & $0(0.0)$ & $12.1(8)$ & $51.5(34)$ & $36.4(24)$ \\
\hline $\begin{array}{l}\text { Fund value enables LAPF to } \\
\text { develop employees in terms of } \\
\text { skills and knowledge }\end{array}$ & $0(0.0)$ & $0(0.0)$ & $31.8(21)$ & $47(31)$ & $21.2(14)$ \\
\hline $\begin{array}{l}\text { Fund value enables LAPF to pay } \\
\text { tax for all its investment }\end{array}$ & $1.5(1)$ & $0(0.0)$ & $19.7(13)$ & $54.5(36)$ & $24.2(16)$ \\
\hline
\end{tabular}

Source: Field data (2018)

Findings on the influence of fund value on performance revealed that majority of respondents who were $94 \%$ commented that excess fund enables LAPF to conduct more investments, $86.4 \%$ agreed that excess fund leads to more benefits for members, $74.2 \%$ agreed that excess fund enables LAPF to grant loans to its customers at a reasonable interest rate, 75.7\% quantified that excess fund enables LAPF to pay lump sum to retirees, invalids, and survival. Moreover, the respondents stated that fund value enables LAPF to grow in terms of number of branches and services, $68.2 \%$ also pointed out that it enables LAPF to develop its employees in terms of skills and knowledge whereas $78.7 \%$ specified that fund value enables the fund to pay for tax for all its investments. The findings contradict with the findings of Bodie, Detemple, and Rindisbacher, (2009) who argued that fund value has a strong bearing on the financial performance of pension funds in the long run. This study did not a find strong relationship between fund value and the returns of the pension funds indicating that fund value does not 
affect performance of the pension funds. This study found that fund size does not have a significant effect on performance.

\subsection{Relationship between Assets and Performance of Pension Fund}

The Researcher posed a number of questions to assess the relationship between assets and the performance of the pension fund. The findings are indicated in Table 4.3 below:

Table 4.3 Relationship between Assets and Pension Fund Performance

\begin{tabular}{|l|c|c|c|c|c|}
\hline & $\begin{array}{c}\text { Strongly } \\
\text { Disagree }\end{array}$ & Disagree & Neutral & Agree & $\begin{array}{c}\text { Strongly } \\
\text { Agree }\end{array}$ \\
\hline $\begin{array}{l}\text { Rent obtained from LAPF assets enable it to } \\
\text { cover operational costs }\end{array}$ & Perc (Frq) & Per (Frq) & Per (Frq) & Per (Frq) & Per (Frq) \\
\hline $\begin{array}{l}\text { Rent obtained from LAPF assets are used to pay } \\
\text { interests to members annually }\end{array}$ & $0(0.0)$ & $0(0.0)$ & $21.2(14)$ & $57.6(38)$ & $21.2(14)$ \\
\hline $\begin{array}{l}\text { Rent obtained from assets are re-invested } \\
\text { Rent from assets are used to improve services } \\
\text { through use of technology in service provision }\end{array}$ & $0(0.0)$ & $0(0.0)$ & $22.7(15)$ & $59.1(39)$ & $18.2(12)$ \\
\hline $\begin{array}{l}\text { Dividends obtained from shares enable LAPF to } \\
\text { invest more }\end{array}$ & $0(0.0)$ & $1.5(1)$ & $6.1(4)$ & $63.6(42)$ & $28.8(19)$ \\
\hline tertiary bills enable LAPF to get interests & $0(0.0)$ & $0(0.0)$ & $12.1(8)$ & $53(35)$ & $34.8(23)$ \\
\hline
\end{tabular}

Source: Field data (2018)

Results in table 4.3 show that; $89.4 \%$ of the respondents agreed that rent obtained from LAPF assets enable it to cover operational costs, $78.8 \%$ stated that rent obtained from assets are used to pay interests to members annually. Correspondingly, $80.3 \%$ of the respondents confirmed that rent enabled LAPF to re-invest, $77.3 \%$ pointed out that obtained rent is used to improve LAPF performance specifically improving services by using technology. Moreover, $81.8 \%$ agreed that fixed deposits enable LAPF to get interest, $91.6 \%$ agreed that dividends obtained from shares enable LAPF to invest more and $87.8 \%$ believed that government securities such as bonds and tertiary bills enable the fund to get interest as well. The foregoing findings are contrary to the study carried out by Kagunda (2011) which show that asset allocation can explain a significant amount of difference in returns across time and hence a primary determinant of return performance of unit trusts in Kenya.

\subsection{Influence of Members' Contributions towards Pension Performance}

The study also assessed the influence of members' contributions on pension performance and the results are indicated in Table 4.4 below as follows: 
Table 4.4 Members' Contribution influence Pension Fund Performance

\begin{tabular}{|l|c|c|c|c|c|}
\hline & $\begin{array}{c}\text { Strongly } \\
\text { Disagree }\end{array}$ & Disagree & Neutral & Agree & $\begin{array}{c}\text { Strongly } \\
\text { Agree }\end{array}$ \\
\hline $\begin{array}{l}\text { Members contribution enable LAPF to } \\
\text { conduct more investments }\end{array}$ & Perc (Frq) & Per (Frq) & Per (Frq) & Per (Frq) & Per (Frq) \\
\hline $\begin{array}{l}\text { More investment from contributions enable } \\
\text { LAPF to increase its number of assets }\end{array}$ & $0(0.0)$ & $0(0.0)$ & $7.6(5)$ & $71.2(47)$ & $21.2(14)$ \\
\hline $\begin{array}{l}\text { Members contributions increase liquidity of } \\
\text { the fund which facilitate payment of } \\
\text { pensioners }\end{array}$ & $0(0.0)$ & $0(0.0)$ & $21.2(14)$ & $45.5(30)$ & $33.3(22)$ \\
\hline $\begin{array}{l}\text { The density of contribution influences the } \\
\text { number of benefits }\end{array}$ & $0(0.0)$ & $3(2.0)$ & $30.3(20)$ & $56.1(37)$ & $19.6(7)$ \\
\hline $\begin{array}{l}\text { Members contributions ensure fund } \\
\text { sustainability/ survival }\end{array}$ & $0(0.0)$ & $0(0.0)$ & $12.1(8)$ & $53(35)$ & $34.8(23)$ \\
\hline $\begin{array}{l}\text { Members contributions enable LAPF to } \\
\text { cover some operational costs }\end{array}$ & $0(0.0)$ & $6.1(4)$ & $7.6(5)$ & $65.2(43)$ & $21.2(14)$ \\
\hline $\begin{array}{l}\text { Members contributions facilitate quick } \\
\text { payment to pensioners }\end{array}$ & $0(0.0)$ & $0(0.0)$ & $21.2(14)$ & $57.6(38)$ & $21.2(14)$ \\
\hline
\end{tabular}

Source: Field data (2018)

Findings in table 4.4 above reveal that $92.4 \%$ of the respondents were of the view that members' contributions enable LAPF to conduct more investments, $92.4 \%$ agreed that more investment from contributions enable LAPF to increase its number of assets.78.8\% were of the opinion that members' contribution increase liquidity of the fund which facilitates payment of pensioners. $75.7 \%$ agreed that the density of contribution influences the number of benefits, whereas $86.4 \%$ opined that members' contributions enable LAPF to cover some operational costs. $87.8 \%$ of the respondents mentioned that members' contributions ensure fund sustainability/ survival and $78.8 \%$ agreed that members' contributions facilitate quick payment to pensioners.

\subsection{How the Age of the Investor affects Performance of a Pension Fund.}

It is believed that the age of the investor largely affects performance of the pension fund. Therefore, the Researcher resolved to set questions in order to confirm this assertion. Results as indicated in table 4.5 below. 
Table 4.5 The Age of Investor affects Performance of a Pension Fund

\begin{tabular}{|l|c|c|c|c|c|}
\hline & $\begin{array}{c}\text { Strongly } \\
\text { Disagree }\end{array}$ & Disagree & Neutral & Agree & $\begin{array}{c}\text { Strongly } \\
\text { Agree }\end{array}$ \\
\hline & Perc (Frq) & Per (Frq) & Per (Frq) & Per (Frq) & Per (Frq) \\
\hline $\begin{array}{l}\text { Longer period of contribution increase more } \\
\text { contribution which facilitates investment }\end{array}$ & $0(0.0)$ & $0(0.0)$ & $9.1(6)$ & $62.1(41)$ & $28.8(19)$ \\
\hline $\begin{array}{l}\text { Longer period of contribution increases } \\
\text { liability }\end{array}$ & $0(0.0)$ & $1.5(1)$ & $18.2(12)$ & $66.7(44)$ & $13.6(9)$ \\
\hline $\begin{array}{l}\text { Younger members contribute for a longer } \\
\text { period of time compared to older members }\end{array}$ & $0(0.0)$ & $0(0.0)$ & $7.6(5)$ & $54.5(36)$ & $37.9(25)$ \\
\hline $\begin{array}{l}\text { Longer period of contribution ensures } \\
\text { survival of the Pension fund }\end{array}$ & $0(0.0)$ & $0(0.0)$ & $9.1(6)$ & $60.6(40)$ & $30.3(20)$ \\
\hline $\begin{array}{l}\text { Longer period of contribution ensures the } \\
\text { liquidity of the fund }\end{array}$ & $0(0.0)$ & $1.5(1)$ & $10.6(7)$ & $51.5(34)$ & $36.4(24)$ \\
\hline
\end{tabular}

Source: Field data (2018)

Results in table 4.5 above shows that $90.9 \%$ of the respondents agreed that a longer period of contribution increases more contribution and facilitates investment. $80.3 \%$ of the respondents were of the view that a longer period of contribution increases fund liability and likewise $92.4 \%$ agreed that a younger members contribute for a longer period compared to their older counterparts. Moreover, $87.9 \%$ of the respondents agreed that a longer period of contribution ensures the liquidity of the fund.

\subsection{Regression Analysis}

Upon measuring the influence of fund value, assets, age of investors and members' contributions on performance of pension fund by using regression analysis and the aggregate figure, the results exposed the fact that members' contributions have a weak relationship with a coefficient of 0.761 , followed by the age of investors which was found to have a positive significant effect with a value of 0.601 .The fund value had a coefficient value of 0.591 while assets had a weak coefficient value of 0.070 .

\section{Model Summary}

\begin{tabular}{|l|r|r|r|r|}
\hline Model & R & R Square & Adjusted R Square & Std. Error of the Estimate \\
\hline 1 & $.538^{\mathrm{a}}$ & .290 & .243 & 6.12956 \\
\hline
\end{tabular}

a. Predictors: (Constant), AGE, AS, FV, CN

ANOVA $^{\mathrm{a}}$

\begin{tabular}{|c|c|c|c|c|c|c|}
\hline \multicolumn{2}{|c|}{ Model } & Sum of Squares & $\overline{d f}$ & Mean Square & $\bar{F}$ & Sig. \\
\hline \multirow{3}{*}{1} & Regression & 920.260 & 4 & \multirow{3}{*}{$\begin{array}{r}230.065 \\
37.572\end{array}$} & \multirow[t]{3}{*}{6.123} & \multirow[t]{3}{*}{$.000^{\mathrm{b}}$} \\
\hline & Residual & 2254.294 & 60 & & & \\
\hline & Total & 3174.554 & 64 & & & \\
\hline
\end{tabular}


Table 4.6 Regression output on the Factors influencing Performance of Pension Funds

\begin{tabular}{|l|r|r|r|r|r|}
\hline \multirow{2}{*}{ Model } & \multicolumn{2}{|c|}{ Unstandardized Coefficients } & \multicolumn{1}{c|}{$\begin{array}{c}\text { Standardized } \\
\text { Coefficients }\end{array}$} & \multicolumn{1}{c|}{ Sig. } \\
\cline { 2 - 4 } & \multicolumn{1}{|c|}{ B } & Std. Error & Beta & & \\
\hline (Constant) & -32.708 & 12.065 & & -2.711 & .009 \\
FV & .591 & .356 & .195 & 1.657 & .103 \\
AS & .070 & .179 & .044 & .388 & .699 \\
CN & .761 & .394 & .263 & 1.931 & .058 \\
AGE & .601 & .370 & .214 & 1.624 & .110 \\
\hline
\end{tabular}

a. Dependent Variable: PERF

\subsection{Reliability and Validity of the Study}

\subsubsection{Reliability of the Study}

The reliability of data instruments was evaluated through the Split-Half Reliability test that can be calculated through the reliability index by coefficient alpha, Kuder-Richardson formula 20 (KR-20) or the Spearman-Brown formula to determine how much error in a test score is due to poor test construction. In this regard, the coefficient alpha or Cronbach's Alpha was used to evaluate the reliability of the study because "If you administer a Likert Scale or have another measure that does not have just one correct answer, the preferable statistic to calculate the split-half reliability is coefficient alpha or called Cronbach's alph" (Korb, 2013). Table 4.7 shows the value of the coefficient alpha or Cronbach's alpha as the research scale is 0.878 or $87.8 \%$. This is over $80 \%$, which is an extra good value for the internal consequence of the conceptual construction of the investigated scale.

\begin{tabular}{|r|r|}
\hline \multicolumn{4}{|c|}{ Table 4.7 Reliability Statistics } \\
\hline Cronbach's Alpha & N of Items \\
\hline & .878 \\
\hline
\end{tabular}

Source: Field data

\subsubsection{Validity of the Study}

The validity of the study was measured using the Kaiser-Meyer-Olkin (KMO) and Bartlett's Test of sphericity through the SPSS. Results extracted from SPSS are presented in table 4.8 below regarding the two hypotheses of factor analysis. From table 4.8, the researcher found a sample sufficiency index of KMO by Kaiser-Meyer-Olkin, which compares the sizes of the observed correlation coefficients to the sizes of the partial correlation coefficients for the sum of analysis variables which is 0.762 or $76.2 \%$, and is reliable because it is above 0.5 or $50 \%$ which is the cut-off. In addition, the supposition test of sphericity by the Bartlett test (Ho: All correlation coefficients are not quite far from zero) is rejected on a level of statistical significance $p<0.0005$ for Approximation, so that the second acceptance of factor analysis is satisfied.

\begin{tabular}{|l|l|r|}
\hline \multicolumn{2}{|c|}{ Table 4.8 KMO and Bartlett's Test } \\
\hline \multicolumn{2}{|c|}{ Kaiser-Meyer-Olkin Measure of Sampling Adequacy. } & .762 \\
\hline \multirow{3}{*}{ Bartlett's Test of Sphericity } & Approx. Chi-Square & 57.263 \\
\cline { 2 - 3 } & df & 10 \\
\cline { 2 - 3 } & Sig. & .000 \\
\hline
\end{tabular}

Source: Field data 


\subsection{Conclusion}

From the findings of this research, a number of conclusions can be made. Firstly, the relationship between the fund value, the age of investors, members' contributions and assets, and fund performance funds in LAPF are not strong. This means that improvement in the value of pension funds is not used as leverage for higher profitability. Improvement in fund values does not translate to higher returns. The study concluded that the age of investors and members' contributions has a higher coefficient value to pension performance. The relationship between assets and returns is also weak. This leads to the conclusion that the assets acquired by the pension scheme do not translate into higher returns. If the relationship was strong, then it would mean that the assets available in the pension funds are used to generate income for the generation of income for the benefit of the contributors. However, this is not the case.

\section{REFERENCES}

Ammann, M and Ehmann, C (2014), Is Governance Related to Investment Performance and Asset Allocation? Empirical Evidence from Swiss Pension Funds University of St. Gallen, School of Finance Research Paper No. 2016/23.

Bodie, Z., Detemple, J. \&Rindisbacher, M., (2009). Life Cycle Finance and the Design of Pension Plans. 2009. Boston University School of Management.

Davis, E.P. (1995), "Pension Funds, Retirement-Income Security and CapitalMarkets, an International Perspective", Oxford University Press.

Davis, E. (2000) Pension Funds, Financial Intermediation and the New Financial Landscape. The Pensions Institute, Discussion Paper No. P1-0010.

Impavido, G., Tower, I., (2009), How the Financial Crisis Affects Pensions and Insurance and Why the Impacts Matter"e, IMF Working Paper.

Kagunda, T. (2011). Asset Allocation by Fund Managers and the Financial Performance of Assets in Kenya. Unpublished MBA Project, University of Nairobi".

Kiplagat, M.K., (2014). The Effect of Asset Allocation and Performance of Pension

Funds in Kenya, Unpublished MBA Project, University of Nairobi.

Meng, A.andPfau, W. (2010) The Role of Pension Funds in Capital Market Development. GRIPS Discussion Paper 2017.

Nguthu (2009). The effects of assets allocation on Retirement Benefits Funds Performance in Kenya. Unpublished MBA PROJECT University of Nairobi

Omondi,E.A.,(2013).The Relationship Between Asset Allocation AND Performance of Pension Fund in Kenya. Unpublished MBA Project University of Nairobi

Puttonen,V. (2005). Asset Allocation in Finnish Pension Funds. Journal of Pension Economics and Finance.

Sawicki, J \& Ong, F 2000, 'Evaluating managed fund performance using conditional measures: Australian evidence' Pacific-Basin Finance Journal, vol 8, no. 3-4, pp. 505-528

Walker, E. \& Iglesias, A. (2010). Financial Performance of Pension Funds: An exploratory study. 